\title{
A Designed Energy Management System (EMS) for an Off- Grid Residential Microgrid
}

\author{
Olivier Kiraga Cyubahiro ${ }^{1 a}$, Martial Giraneza ${ }^{1 b}$, Khaled Abo-Al-Ez ${ }^{1 c}$, \\ Mohamed Tariq E. Kahn ${ }^{1 d}$
}

RECEIVED ON 21.04.2021, ACCEPTED ON 13.09.2021

\begin{abstract}
This paper proposes an Energy Management System (EMS) of an off-grid residential microgrid comprised of a solar photovoltaic array, wind turbine, and a battery-based energy storage system for a residential building in a remote area. The aim is to design a less complex energy management system that addresses energy resources dispatch challenge in a hybrid residential microgrid. It equitably dispatches resources and manages the generated energy to meet the residential load. The management control system algorithm is implemented using the state machine and simulated in MATLAB/Simulink environment for validation. Three scenarios are simulated, they emulate various contingencies scenarios that might rise due to the intermittency nature of the renewable resources. Simulation results show that the proposed energy management system achieves its design objectives. It maintains the power supply and demand balance, through an appropriate scheduling of resources even during contingency due to the intermittence nature of the renewable resources.
\end{abstract}

Keywords: Photovoltaic system, Wind system, Battery, Micro-grid, State machine, Energy Management, Supply-demand balance.

\section{INTRODUCTION}

$\Lambda$ ccess to energy in rural and urban areas is a challenge in developing countries. The reliability of power supply in electrified areas and environmental awareness opens the door for microgrids. The microgrid concept is established as an alternative solution for electrification for remote areas and as a platform for renewable energy integration in urban and suburban networks. Microgrids are defined as a cluster of loads and power generating units operating as a single controllable system with the ability to be connected or not to a grid [1]. Environmental concern and energy security are the main motivations for microgrids concept development [2]. The decarbonisation of the energy production approach to address environmental concerns sets up space and opportunity for microgrids to flourish [3]. Furthermore, the microgrid concept has proved to be an economical alternative to the traditional top-down grid extension for remote areas and improved the reliability of energy supply in urban areas. In addition, it provides the opportunity to cut the cost of energy in urban areas while relieving the pressure off the traditional grid [4-6]. The early application of microgrids was in data centres, military bases and remote rural areas [7, 8]. Microgrids can be classified as grid-connected or off-grid depending on their mode of operation. They can also be classified as DC or AC microgrids depending on the nature of generated current. Microgrids are also classified according to the beneficiaries or end-users. Thus they can be residential microgrids for one household or community microgrids for the entire community $[9,10]$. A

${ }^{1}$ Centre for Distributed Power and Electronic Systems (CDPES), Cape Peninsula University of Technology (CPUT) PO Box 1906, Bellville 7535, Cape Town, South Africa.

Email: ${ }^{a}$ cyubahiro83@yahoo.fr, ${ }^{b}$ giranezam@cput.ac.za (Corresponding Author), ${ }^{c}$ aboalezk@cput.ac.za, dkhant@cput.ac.za

This is an open access article published by Mehran University of Engineering and Technology, Jamshoro under CC BY 4.0 International License. 
residential microgrid usually consists of a generation unit or facility, the power conditioning equipment and residential loads, and the grid integration interface for grid-connected operation. Justo et al. [11] have presented a comparison of both systems and analyzed multiple aspects of microgrids benefits. Microgrids can be based on single or multiple renewable technologies. The latter is also referred to as a hybrid microgrid. It has higher reliability than a single technology microgrid, which is limited by the intermittence nature of the renewable source [12]. Thus, hybrid microgrids are characterized by different renewable energy resources, technologies and an energy storage system for an increased power supply reliability. Furthermore, diesel generators can also be associated with a microgrid to form a high reliable hybrid microgrid system immune to the effects of renewable resources intermittently [13, 14].

Nevertheless, the benefits mentioned above of a hybrid microgrid system come with challenges: managing various intermittent resources to match the demand. Thus the control strategy, energy and power management schemes are critical aspects for hybrid microgrid operation [15]. The power management deals with operational regulation and interface parameters for each source within the microgrid, while energy management deals with the optimal matching of the load to the available, total power production [16-18]. In microgrids, the energy management system relies on control strategies software to achieve optimal resources [19, 20].

Various authors reported on different strategies in regards to the energy management system in hybrid microgrids. A comparative analysis of energy management systems is presented in [21]; the authors compared three dispatch strategies for a hybrid energy system consisting of renewable resources, a diesel generator and an energy storage system. The three strategies are cycle charging, peak shaving and load following. They found that the cycle charging strategy was cost-effective. Olatomiwa et al. [22] presented a comprehensive review on energy management strategies in hybrid renewable energy. They analyzed various techniques and strategies used in isolated and grid-connected microgrids. The review scoped the popular approaches into linear programming and artificial intelligence approach, energy management on linear programming or artificial intelligence for a standalone and grid-connected microgrid. It was concluded that the best approach depended on the context and type of renewable energies involved. In [23] a linear programming based energy management system is presented for an islanded hybrid microgrid. The developed algorithm aimed at maintaining the supply-demand balance within the microgrid. An energy management system based on a hybrid automata algorithm and a propositional-based logic is presented in [24] for an islanded microgrid.

Most authors focused on energy management systems for application in grid-tied residential microgrids with enhanced features such as energy prediction, which rely on communication, thus rendering the system complex and expensive for application in off-grid rural areas [25]. Therefore, this paper proposes a simple, reliable and affordable algorithm for an EMS for an off-grid residential microgrid in rural areas. The system is less complex and operates based on the current status of the available resources and the residential demand, with no need for communication. The paper is organized as follows: Section 2 describes the residential microgrid. Section 3 covers the proposed energy management system for the microgrid. Section 4 presents the simulation results, and Section 5 concludes the paper.

\section{SYSTEM DESCRIPTION}

The proposed algorithm for the energy management system is applied to a residential off-grid microgrid. The latter consists of a photovoltaic unit (PV), a small wind turbine, an energy storage system (battery bank) and the load. The loads are categorized into three categories: AC, DC, and dump load for energy excess cases. The hybrid microgrid is configured as shown in Fig. 1, and a DC network is used to integrate the renewable resources. Power electronic interfaces are used for wind and PV and $\mathrm{AC}$ load interconnection to the $\mathrm{DC}$ bus. The PV and wind operate as the primary sources to supply the house loads (AC and DC). A battery-based energy storage is used to mitigate fluctuations in energy from the intermittence nature of the primary sources. The overall sizing of the microgrid was done using Homer software. 


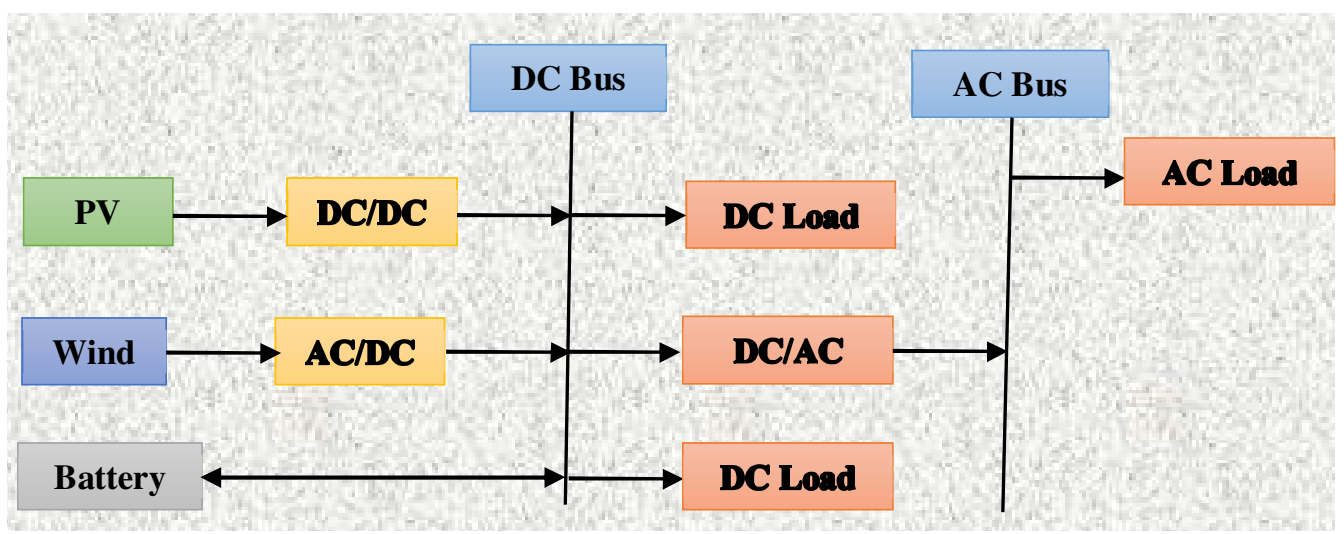

Fig. 1: Block diagram of a microgrid renewable system comprised of solar PV-wind, and battery hybrid system

\subsection{Photovoltaic system}

The PV system is developed around photovoltaics cells, represented by its equivalent diode model shown in Fig. 2. It consists of a current source and a PN junction parallel with a shunt resistor Rsh and series resistor $R_{p}$. The series resistance represents the ohmic losses which occur through the electrical contacts and the resistivity of the cell material, the shunt or parallel resistance $R_{p}$ is equivalent of the losses in the junction, the $I_{d}$ is the diode current when forward biased, $I_{p h}$ the photocurrent generated current by the cell due to the solar irradiation. I is the output current at the terminals of the solar cell, expressed by equation (1).

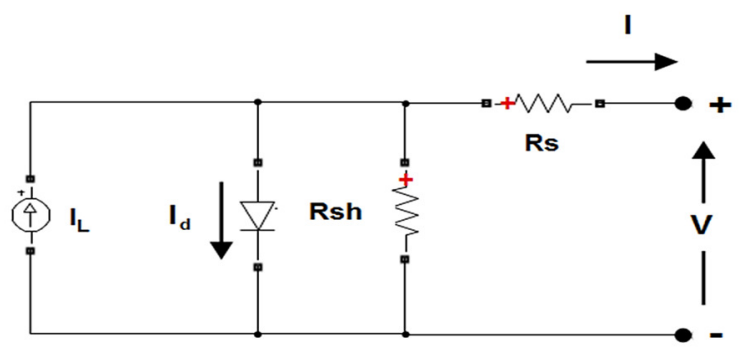

Fig. 2: Equivalent circuit of a photovoltaic model with a single diode

$I=I_{p h}-I_{o}\left[\left(e^{\frac{v}{A V_{T}}}-1\right)-\left(\frac{V_{T}+I R_{S}}{R_{S h}}\right)\right]$

In the above equation, $\mathrm{A}$ is the ideality factor of the diode, and $\mathrm{V}_{\mathrm{T}}$ is called thermal voltage, $\mathrm{V}$ is the voltage imposed on the diode, $I_{0}$ is the leakage current or the reverse saturation current of the diode, and $\mathrm{I}_{\mathrm{ph}}$ is the photocurrent. The output power $\mathrm{P}_{\mathrm{PV}}(\mathrm{t})$ of $\mathrm{PV}$ system in $\mathrm{kW}$ at time $\mathrm{t}$ is calculated using equation (2) [26]:
$P^{P V}(t)=\eta^{P V} \cdot A^{P V} \cdot I_{r}(t) \cdot\left(1-0.005\left(T^{a}(t)-25\right)\right)$

where:

$\eta^{\mathrm{PV}}=$ energy conversion efficiency of the PV system (\%)

$\mathrm{A}^{\mathrm{PV}} \quad=$ area of the generator in $\left(\mathrm{m}^{2}\right)$,

$\mathrm{I}_{\mathrm{r}}(\mathrm{t})=$ solar irradiance $(\mathrm{kW} / \mathrm{m} 2)$ at time $\mathrm{t}$,

$0.005=$ temperature correction factor [27],

$\mathrm{T}^{\mathrm{a}}(\mathrm{t})=$ outdoor temperature $\operatorname{in}\left({ }^{\circ} \mathrm{C}\right)$ at time $\mathrm{t}$ and

$25=$ standard room temperature $\left({ }^{\circ} \mathrm{C}\right)$

\subsection{Wind System}

A small power wind turbine with a horizontal axis permanent magnet synchronous generator is used. The wind turbine converts wind kinetic energy into mechanical energy to drive the generator that produces electrical energy. The turbine's input wind power converted into mechanical power is expressed by equation (3), where $A$ is the wind turbine area through which the wind is flowing, and $\rho$ is the air density.

$\mathrm{P}=\frac{1}{2} \rho A v_{\mathrm{w}}^{3}$

The extracted mechanical power from wind in watts is given by equation (4), where $v_{u}$ is the upstream wind velocity at the entrance of the rotor blades in $\mathrm{m} / \mathrm{s}$ and $v_{\mathrm{d}}$ is the downstream wind velocity at the exist of the Rotor blades in $\mathrm{m} / \mathrm{s}$.

$\mathrm{P}_{\omega}=\frac{1}{2} \rho A v_{\omega}\left(v_{\mathrm{u}}^{2}-v_{\mathrm{d}}^{2}\right)$

and knowing that 


$$
\begin{aligned}
\rho A v_{\omega} & =\frac{1}{2} \rho A\left(v_{\mathrm{u}}+v_{\mathrm{d}}\right) \\
\mathrm{P}_{\omega} & =\frac{1}{2}\left[\rho \mathrm{A}\left\{\frac{v_{\mathrm{u}}}{2}\left(v_{\mathrm{u}}^{2}-v_{\mathrm{d}}^{2}\right)+\frac{v_{\mathrm{d}}}{2}\left(v_{\mathrm{u}}^{2}-\mathrm{v}_{\mathrm{d}}^{2}\right)\right\}\right] \\
& =\frac{1}{2}\left[\rho A\left\{\frac{v_{u}^{3}}{2}-\frac{v_{u} v_{d}^{2}}{2}+\frac{v_{d} v_{u}^{2}}{2}-\frac{v_{d}^{3}}{2}\right\}\right] \\
& =\frac{1}{2}\left[\rho A v_{u}^{3}\left\{\frac{1-\left(\frac{v_{d}}{v_{u}}\right)^{2}+\left(\frac{v_{d}}{v_{u}}\right)-\left(\frac{v_{d}}{v_{u}}\right)^{3}}{2}\right\}\right] \\
\mathrm{P}_{\omega} & =\frac{1}{2} \rho A V_{\mathrm{u}}^{3} \mathrm{C}_{\mathrm{p}}
\end{aligned}
$$

where $\mathrm{Cp}$ is the wind turbine rotor power coefficient or Betz limit.

\subsection{Energy Storage System}

Energy Storage System (ESS) is used to store energy excess from the main supply, PV and Wind turbine. The stored energy will be used as a backup during power shortages due to the intermittence nature of the main supply. Batteries are used as an energy storage system. The storage takes place when its state of charge is below $40 \%$. The discharge is triggered by a command from the energy management system when an imbalance between the main supply (PV \& wind) and the loads occurs. The energy stored at time $t$ is characterized by equation (8) [26]:

$E s(t)=E s(t-1)+\kappa \cdot \eta^{E s s} \cdot E \cdot P^{c h}(t)-\frac{\kappa \cdot E P^{D c h}(t)}{\eta^{E s s}}$

where

Es = energy stored in $\mathrm{kWh}$ at time $\mathrm{t}$,

$\kappa \quad=$ time slot

$\eta^{\text {Ess }} \quad=$ battery efficiency

$\mathrm{EP}^{\mathrm{Ch}}=$ Power stored by the Battery at time $\mathrm{t}$,

$\mathrm{EP}^{\mathrm{Dch}}=$ Power discharged by the battery to the load at time $\mathrm{t}$

\section{EMS DESIGN}

The state machine system monitors, controls, and shares energy due to its efficiency and robustness. Hence state machine control has been implemented for energy flow management between intermittent sources and the load. Note that in the present paper, the loads are clustered as load 1or load 2. In this paper, the following conditions are used for energy management:

- Conditions of state machine control system

- $\quad$ If $\mathrm{P}_{\text {ren }} \geq \mathrm{P}_{\text {Load }} \& \&$ SOC $<40 \%$

Charging $=1 ;$ Discharging $=0 ; \quad$ Load $10 n=1 ;$ Load2On= $1 ; \mathrm{D}_{\text {Load }}=0$;

The power from renewable sources, $\mathrm{P}_{\mathrm{ren}}$, will be used to supply the load, and the excess will be used to charge batteries.

- If $\mathrm{P}_{\text {ren }} \geq \mathrm{P}_{\text {Load }} \& \&$ SOC $>40 \%: \& \& S O C<$ $90 \%$

Charging $=1 ;$ Discharging $=0 ; \quad$ Load $1 \mathrm{On}=1 ;$ Load2On $=1 ; \mathrm{D}_{\text {Load }}=0$;

In this case, the main power $\mathrm{P}_{\mathrm{ren}}$ available is greater than the demand, and the battery state of charge is at the nominal level of charge; thus, it can charge or discharge at any time. Therefore, the excess power from renewable energy will be used to charge the batteries.

- If $\mathrm{P}_{\text {ren }} \geq \mathrm{P}_{\text {Load }} \& \&$ SOC $>90 \%$

Charing $=0 ;$ Discharging $=0 ;$ Load1On $=1$;

$\operatorname{Load} 2 \mathrm{On}=1 ; \mathrm{D}_{\text {Load }}=1$;

In this case, as the SOC of the battery is at its highest level of charging, the excess power from renewable energy will be channeled to the dump load to avoid damage to the battery bank due to over-charging.

- If else $\mathrm{P}_{\text {ren }}<\mathrm{P}_{\text {Load }} \& \& 40<\mathrm{SOC}<90 \%$ Charging $=0$; Discharging $=1 ; \operatorname{Load} 1 \mathrm{On}=1 ; \operatorname{Load} 2 \mathrm{On}=$ $1 ; \mathrm{D}_{\text {Load }}=0$;

If the renewable energy supply $P_{\text {ren }}$ cannot sustain the load demand $\mathrm{P}_{\text {Load }}$, the algorithm will check the battery state of charge. If the battery SOC level is between $40 \%$ and $90 \%$, the power will be drawn from batteries to supply the unsatisfied load. Both loads will be connected, but the dump load will not be connected.

- If else $\mathrm{P}_{\text {ren }}<\mathrm{P}_{\text {Load }} \& \&$ SOC $>90 \%$

Charging $=0$; Discharging $=1 ; \operatorname{Load} 1 \mathrm{On}=1 ; \operatorname{Load} 2 \mathrm{On}=$ $1 ; \mathrm{D}_{\text {Load }}=0$; 
In the case of SOC greater than $90 \%$ and the power supplied by the renewable energy source, $\mathrm{P}_{\mathrm{ren}}$ is not enough to sustain the load demand $\mathrm{P}_{\mathrm{Load}}$, and the battery bank provides the power balance, the algorithm will check the status of the SOC of the battery bank and initiate the required action.

$$
\text { - If else } \mathrm{P}_{\text {ren }}<\mathrm{P}_{\text {Load }} \& \& \text { SOC }<40 \%
$$

First condition

$$
\mathrm{P}_{\text {ren }} \geq \mathrm{P}_{\mathrm{L} 1}
$$

Charge $=1 ;$ Discharge $=0 ;$ Load1On $=1 ; \operatorname{Load} 2 \mathrm{On}=0 ;$ $\mathrm{D}_{\text {Load }}=0$;

Second Condition

$$
\mathrm{P}_{\text {ren }} \geq \mathrm{P}_{\mathrm{L} 2}
$$

Charge $=1 ;$ Discharge $=0 ;$ Load $10 n=0 ; \operatorname{Load} 2 \mathrm{On}=1 ;$ $\mathrm{D}_{\text {Load }}=0$;

Otherwise

Charge $=1 ;$ Discharge $=0 ;$ Load 1 On $=0 ; \operatorname{Load} 2 \mathrm{On}=0 ;$ $\mathrm{D}_{\text {Load }}=0$;

In case of power deficit due to the intermittence of the renewable resources coupled to the battery when the SOC is below $40 \%$, the algorithm initiates a loadshedding. The latter tries to match the available power $\mathrm{P}_{\mathrm{ren}}$ to the demand by comparing load 1 and load 2 to the available power $P_{\text {ren. }}$ In the instance of the available power $\mathrm{P}_{\text {ren }}$ is greater than load 1 demand $\mathrm{P}_{\mathrm{L} 1}$, and then the latter is connected while load 2 is disconnected. Otherwise, the available deficit power is compared to the power demand from load $2 \mathrm{P}_{\mathrm{L} 2}$. If $\mathrm{P}_{\mathrm{L} 2}$ is lower than the available power $P_{\text {ren }}$, load 2 is connected while load 1 is disconnected. Otherwise, the management control system disconnects all loads.

\section{SIMULATION AND RESULTS}

To test and validate the performance of the proposed energy management system algorithm, MATLAB/Simulink software environment is used. The residential microgrid load, parameters and renewable resources data modelled and used as a benchmark to test and validated the energy management system are adapted from [28].

\subsection{Parameters}

As shown in Fig. 3, the system comprises of wind and PV systems that supply the power together to sustain the load demand; it also has a battery-based energy storage system. The energy management system controls the battery cycle through switches. The total load consists of AC, DC and dump loads, and the proposed energy management system controls their respective switching in and out from the supply.

The PV model used in this paper is a Soltech PV model and it is a fixed model; the Soltech PV model (and parameters) is available in the Simulink. Therefore, the system is coupled with Maximum Power Point Tracking system known as MPPT, with a Perturb and Observe (P\&O) algorithm to extract the maximum possible power from PV. Table 1 shows the parameters of the photovoltaic module used in this system, they are adapted from [28].

\begin{tabular}{|l|l|}
\hline \multicolumn{2}{|c|}{ Table 1: Photovoltaic input parameter } \\
\hline $\begin{array}{l}\text { Photovoltaic Model input } \\
\text { parameter }\end{array}$ & Value \\
\hline Module & 1 Soltech-230-P \\
\hline Maximum Power $(\mathrm{W})$ & $228.735 \mathrm{~W}$ \\
\hline Open Circuit Voltage Voc $(\mathrm{V})$ & $37.1 \mathrm{~V}$ \\
\hline $\begin{array}{l}\text { Voltage at Maximum } \\
\text { PowerPoint } \mathrm{V}_{\mathrm{mp}}(\mathrm{V})\end{array}$ & $29.9 \mathrm{~V}$ \\
\hline Short-circuit current $\mathrm{I}_{\mathrm{SC}}(\mathrm{A})$ & $8.18 \mathrm{~A}$ \\
\hline $\begin{array}{l}\text { Current at maximum power } \\
\text { point Imp }(\mathrm{A})\end{array}$ & $7.65 \mathrm{~A}$ \\
\hline $\begin{array}{l}\text { Temperature coefficient of } \\
\text { Voc }(\% / \text { deg.C) }\end{array}$ & $0.102 \% /$ deg.C \\
\hline Cells per module $\left(\mathrm{N}_{\text {Cell }}\right)$ & 60 \\
\hline
\end{tabular}

The wind model used in this study is a Permanent Magnet Synchronous Generator (PMSG) with 230V, $5 \mathrm{~kW}$, and $50 \mathrm{~Hz}$. Table 2 shows the parameters of the wind system used as adapted from [28]. The chosen energy storage system is a Lithium-Ion battery based system. Two-rows of 19 Lithium-Ion batteries are connected in series, each with $12 \mathrm{~V}$ and $20 \mathrm{Ah}$, which gives a total of $228 \mathrm{~V}, 20 \mathrm{Ah}$; and an overall $9120 \mathrm{Wh}$. Table 3 shows the parameters of the battery-based energy storage system used in this study as adapted from [28]. 


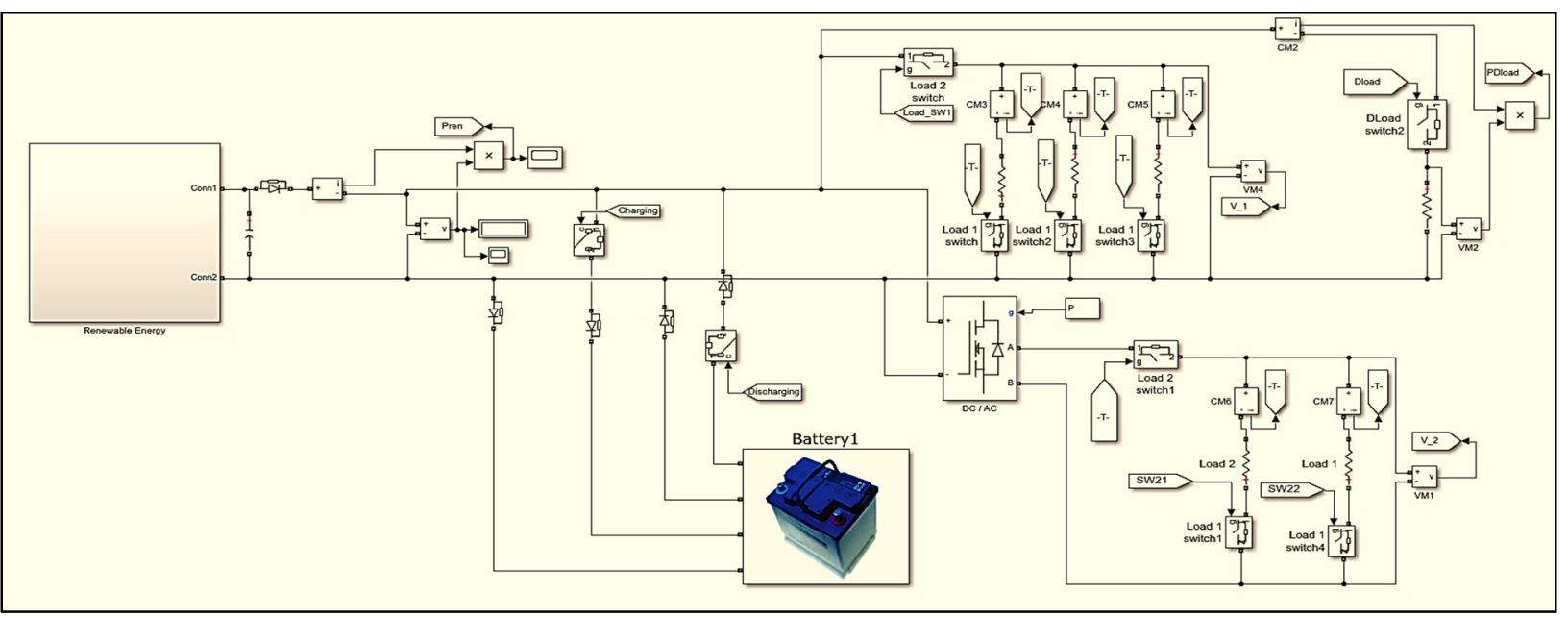

Fig. 3: Overall system design in Matlab/Simulink

\begin{tabular}{|l|ll|}
\hline \multicolumn{3}{|c|}{ Table 2: Wind input parameter } \\
\hline Wind Turbine Parameters & \multicolumn{2}{|l|}{ Value } \\
\hline Mechanical Power output $(\mathrm{kW})$ & 5 & $\mathrm{~kW}$ \\
\hline Cut-in Speed $(\mathrm{m} / \mathrm{s})$ & 1.5 & $\mathrm{~m} / \mathrm{s}$ \\
\hline Base Wind Speed $(\mathrm{m} / \mathrm{s})$ & 12 & $\mathrm{~m} / \mathrm{s}$ \\
\hline Cut-out Speed $(\mathrm{m} / \mathrm{s})$ & 14 & $\mathrm{~m} / \mathrm{s}$ \\
\hline Pitch angle $(\mathrm{deg})$ & 0 & $\mathrm{deg}$ \\
\hline Base rotational speed $(\mathrm{pu})$ & 1 & \\
\hline
\end{tabular}

\begin{tabular}{|l|ll|}
\hline \multicolumn{3}{|c|}{ Table 3: Input parameter of Battery } \\
\hline Battery Model Input Parameters & Unit & \\
\hline Rated battery voltage (V) & 12 & V \\
\hline Battery Capacity (Ah) & 20 & Ah \\
\hline Maximum Capacity of a battery (Ah) & 20 & Ah \\
\hline Fully Charged Voltage (V) & 12 & V \\
\hline Nominal Discharge Current (A) & 6.521 & A \\
\hline State of charge of battery (\%) & 69 & $\%$ \\
\hline Battery Voltage Response time (sec) & 0.1 & sec \\
\hline
\end{tabular}

Table 4: Input parameter of the DC/DC boost converter

\begin{tabular}{|l|l|}
\hline \multicolumn{2}{|c|}{ converter } \\
\hline $\begin{array}{l}\text { Inverter Model Input } \\
\text { Parameters }\end{array}$ & Unit \\
\hline Input Voltage (Vin) & $120 \mathrm{~V}$ \\
\hline Output Voltage (Vout) & $230 \mathrm{~V}$ \\
\hline Converter efficiency & 0.9 \\
\hline Switching Frequency & $15000 \mathrm{~Hz}$ \\
\hline Inductance (L) & $0987789 \mathrm{e}-3 \mathrm{H}$ \\
\hline Capacitance (C) & $37353 \mathrm{e}-4 \mathrm{~F}$ \\
\hline Resistance (R) & $15.343 \Omega$ \\
\hline
\end{tabular}

A boost unidirectional DC-DC converter model is connected to the photovoltaic arrays as an integrator to the residential microgrid. It boosts the PV system output voltage from $120 \mathrm{~V}_{\mathrm{DC}}$ to $230 \mathrm{~V}_{\mathrm{DC}}$. Table 4 shows the parameters of the DC/DC boost converter used in this paper as adapted from [28].

Fig. 4 presents the state machine subsystem in Simulink, and the system intends to monitor and control the flow of energy between these intermittent energies sources. The system has three inputs: $\mathrm{P}_{\text {Load }}$, $\mathrm{P}_{\text {ren }}$ and SOC, load power demand, renewable energy power supply and State of Charge of the battery system, respectively. It is upon the status of the mentioned parameters that the energy management system algorithm bases its decision. The latter is translated into an output control signal for Load 1, Load 2, dump load and battery cycles. The system controls output based on the comparison between input values to decide which output is for the next decision.

Fig. 5 shows the state machine logic when it is in running mode, which is shown by the boundary turning to blue colour. The proposed energy management system algorithm is implemented in state flow in MATLAB/Simulink to share the generated energy equitably. The left side presents the state of the battery comprised of three states: the default, charging, and discharging of a battery. The default describes the state where the battery is not either charging or discharging (charging $=0$; discharging $=0$ ). The other 
state in the battery states is the charging cycle (charging $=1$; discharging=0), in which the battery is taking power from the microgrid main supply for storage. And the last state is the discharging cycle (charging=0; discharging=1), which means that the battery is supplying power to the microgrid. The right side describes the load state comprised of three different loads (Load 1 known as a DC load, Load 2 known as AC load, and dump Load), each one comprised of On and Off state. The arrow describes which state is chosen based on the available power and SOC of a battery.

\subsection{Simulation Results}

Three scenarios have been implemented in this study to test the reliability of the proposed energy management system.

\section{$1^{\text {ST }}$ Scenario}

In this scenario, the initial state of charge of the energy storage system (SOC) is considered as $89 \%$. According to the criteria set, the SOC is in the range where the battery set can run into either cycle or mode: charging or discharging. The algorithm decides the

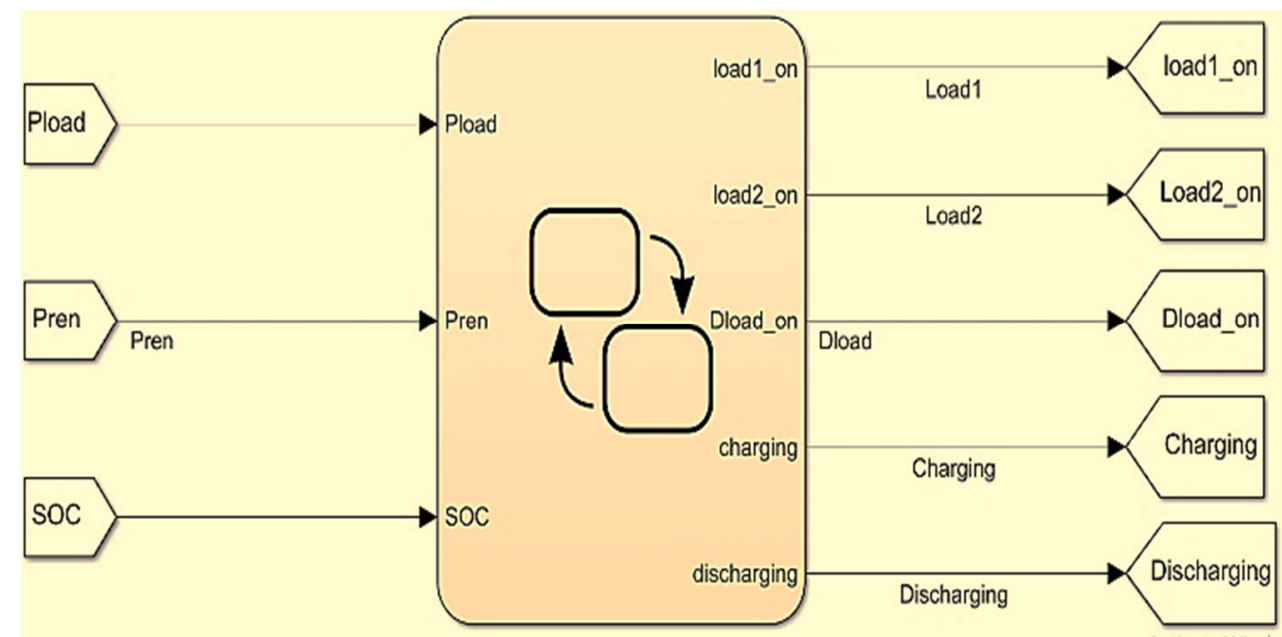

Fig. 4: State machine control block subsystem in Simulink

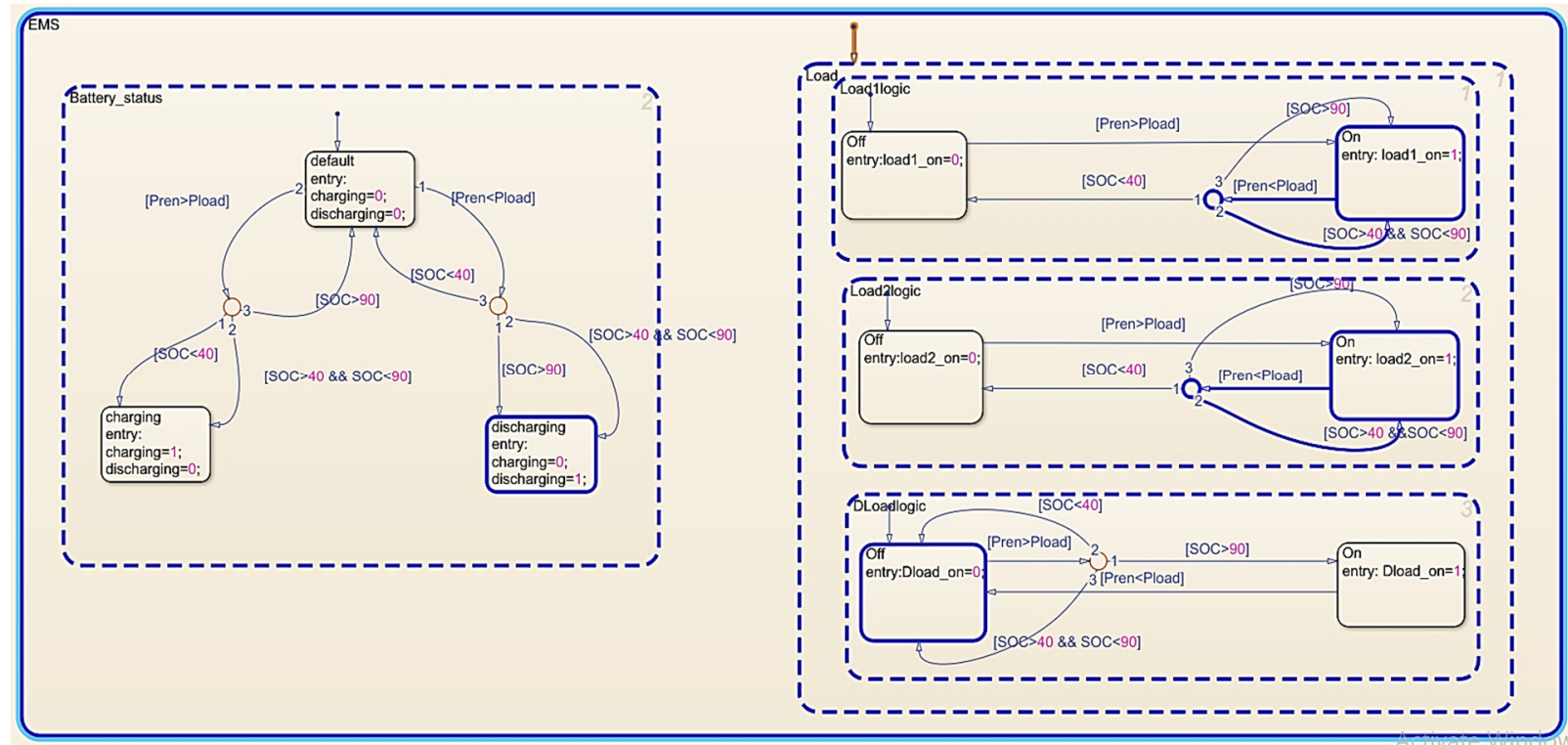

Fig. 5: State machine control diagram 
battery cycle to run with respect to the states or status of the main supply $\mathrm{P}_{\text {ren }}$ and the load demand $\mathrm{P}_{\text {Load. }} \mathrm{A}$ slight variation in wind speed and solar radiations is considered, resulting in the output power variation between $5000 \mathrm{~W}$ and $9000 \mathrm{~W}$; the overall load ranges between $2000 \mathrm{~W}$ and $8000 \mathrm{~W}$.

Fig. 6 shows the simulation results of the load demand, SOC of the battery, power generated by the wind turbine, and power generated by the photovoltaic system. The first row shows that the load profile varies depending on the time. The lowest load recorded is
$2000 \mathrm{~W}$, and the highest load is $8000 \mathrm{~W}$. The second row presents the state of charge of a battery (SOC) which is varying. The 3 rd row presents the power from a wind turbine which is not constant due to the wind speed variation input, the 4 th row presents the power from $\mathrm{PV}$, the $5^{\text {th }}$ row presents the power from renewable energy (wind turbine and PV) with the lowest of $5000 \mathrm{~W}$ and the highest of $9000 \mathrm{~W}$, then the $6^{\text {th }}$ row presents the battery drained or accumulated power. Table 5 shows the results summary of the $1^{\text {st }}$ scenario parameters and results.

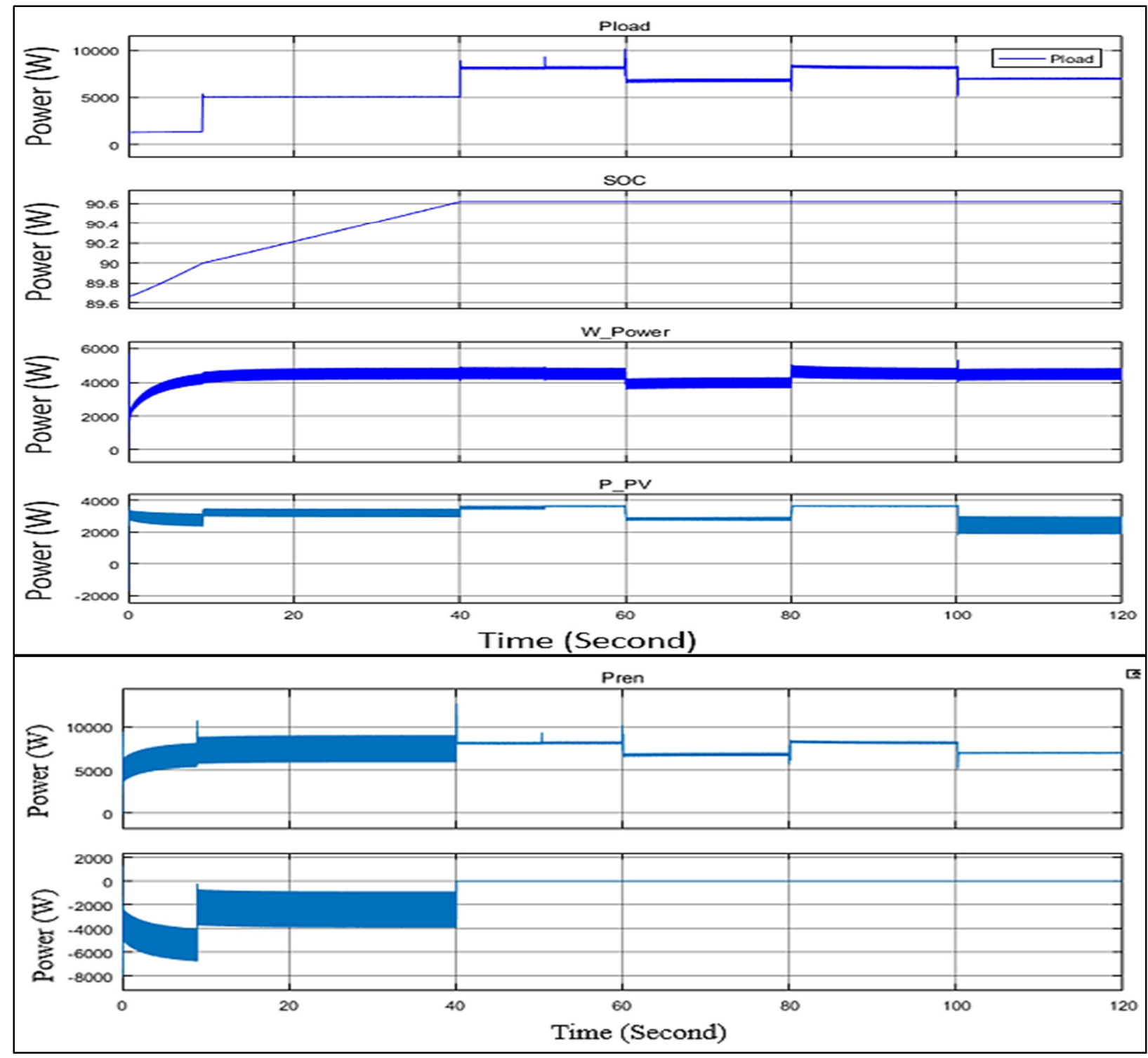

Fig 6: Power Load, SOC of Battery, Wind Power, Photovoltaic Power, Power Generated by Renewable Energy and Battery Power. 


\begin{tabular}{|c|c|}
\hline \multicolumn{2}{|c|}{ Table 5: Result Summary of the $1^{\text {st }}$ scenari } \\
\hline Name & Value \\
\hline Load & $\begin{array}{l}\text { Size }=8000 \mathrm{~W} \\
\text { Highest load }=8000 \mathrm{~W} \\
\text { Lowest load }=2000 \mathrm{~W}\end{array}$ \\
\hline Battery & $\begin{array}{l}\text { Initial } S O C=89 \% \\
S O C_{\min }=40 \% \\
S O C_{\max }=90 \% \\
\text { Battery power }=6900 \mathrm{~W}\end{array}$ \\
\hline $\begin{array}{l}\text { PV+ Wind } \\
\text { Turbine }\end{array}$ & $\begin{array}{l}\text { Maximum power }=9000 \mathrm{~W} \\
\text { Minimum power }=5000 \mathrm{~W} \\
\text { Voltage }=230 \mathrm{~V}\end{array}$ \\
\hline
\end{tabular}

From the results mentioned above, we can see that the proposed energy management successfully tracks the variations in power supply, power demand and the state of the charge of the battery, and its control according to the parameters and conditions as specified in Section 3. From the $10^{\text {th }}$ second, the energy management system algorithm initiates the battery charging as there is enough power supply, and it does stop the charge by $40^{\text {th }}$ seconds, which corresponds to the SOC is $90 \%$, the battery is fully charged to avoid damage due to overcharging. This scenario proves the ability of the algorithm in following up the changes in the supply and dispatching the available resources in consideration of the actual demand. Moreover its control of the battery charging improves the battery lifespan by avoiding the overcharging.

\section{$2^{\text {nd }}$ Scenario}

For this scenario, the battery-based energy storage system, the initial state of charge (SOC) is changed; and the wind turbine power output varying. The SOC is decreased to $48 \%$, the wind turbine output power decreasing for a short period and PV Syst. The load is gradually increasing from an initial $2000 \mathrm{~W}$ to $8000 \mathrm{~W}$. The simulation runs for 120 seconds, and in Table 6 simulation results summary is shown.

From Fig. 7, the first row shows the load variation from the initial start of $2000 \mathrm{~W}$ to a peak load of $8000 \mathrm{~W}$. The latter appears on $60^{\text {th }}$ second to $80^{\text {th }}$ second. At the start, the management system, taking into consideration the demand, will initiate the battery charging as shown on the $2^{\text {nd }}$ row on the same figure. The SOC is increasing consequently. However, at the $60^{\text {th }}$ second, a sudden increase in power demand, as shown $1^{\text {st }}$ row of Figure 7, appears simultaneously with a drop in output power from the wind turbine. This causes an imbalance between the power supply and load demand. The PV system power output remains more or less constant, as shown on the 4th row of Fig, 7. The energy system resolves the imbalance by stopping the charging of the battery, hence the constant SOC for that period. The power towards charging the battery is reallocated to supply the load, which stands at $8500 \mathrm{~W}$. As shown on the $3^{\text {rd }}$ row of Fig. 7, from the $80^{\text {th }}$ second, the wind power output increases again, and the energy management system reconnects back the battery for charging. The $5^{\text {th }}$ row of Fig, 7 shows the battery cycles for the entire period of the simulation. These results show that the proposed algorithm adapts itself to the changes and successfully manages resources under various conditions. This scenario proves the capability of the proposed energy management system to react fast and efficiently to a sudden change in power demand by taking the right decision of load shielding the battery charging and transfer the power available towards the main load.

\begin{tabular}{|l|l|}
\hline \multicolumn{2}{|c|}{ Table 6. Results Summary of the $2^{\text {nd }}$ scenario } \\
\hline Name & \multicolumn{1}{|c|}{ Value } \\
\hline Load & Size $=8000 \mathrm{~W}$ \\
& Highest load $=8000 \mathrm{~W}$ \\
& Lowest load $=2000 \mathrm{~W}$ \\
\hline Battery & Initial $S O C=48 \%$ \\
& SOC $_{\min }=40 \%$ \\
& SOC $_{\max }=90 \%$ \\
& Battery power $=6000 \mathrm{~W}$ \\
\hline PV+ Wind Turbine & Maximum power $=8500 \mathrm{~W}$ \\
& Minimum power $=3000 \mathrm{~W}$ \\
& Voltage $=230 \mathrm{~V}$ \\
\hline
\end{tabular}

\section{$3^{\text {rd }}$ Scenario}

The scenario consists of testing the algorithm's ability to manage energy resources of the residential microgrid in the instance of wind power output drops significantly. The PV system output power drops slightly, but the overall main power supply is reduced, while the load ranges between $3500 \mathrm{~W}$ and a ceiling of $12000 \mathrm{~W}$. The scenario initial SOC is $89 \%$ and the simulation runs for 120 seconds. The combined installed capacity of the renewable resources is $11 \mathrm{kV}$ and battery $9000 \mathrm{~W}$. 


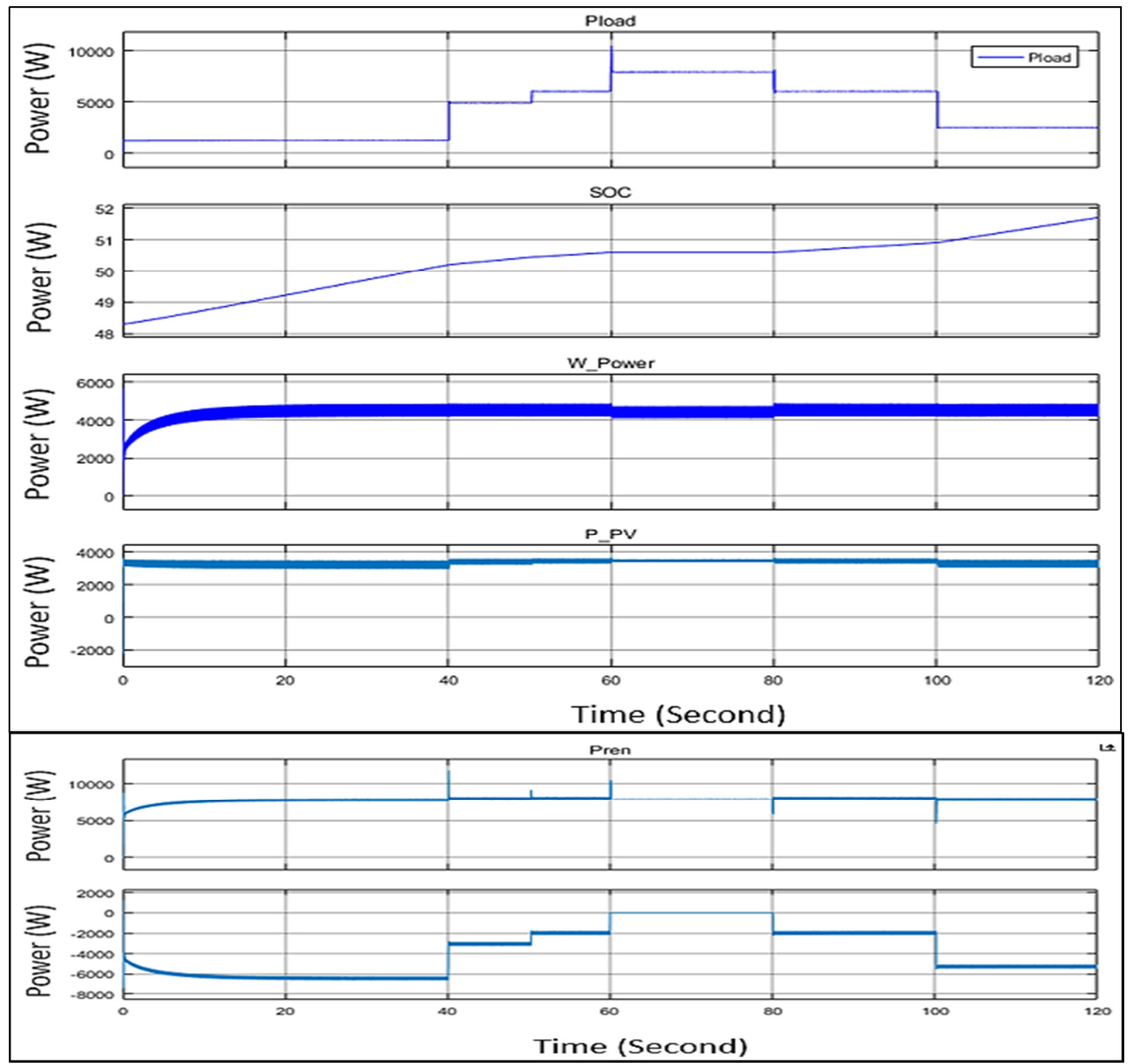

Fig. 7: Power Load, SOC of Battery, Wind Power, Photovoltaic Power, Power Generated by Renewable Energy, and Battery Power

In Fig. 8, the $1^{\text {st }}$ row shows the load curve as it changes; we observe a variation in load demand that increases gradually to achieve a maximum of $12000 \mathrm{~W}$ from the $60^{\text {th }}$ second to $80^{\text {th }}$ second of simulation. On $55^{\text {th }}$ second, we observe on the $3^{\text {rd }}$ row of Fig. 8 a drop in wind turbine output power. It drops to zero; this emulates the intermittence period with no wind; while The PV system output power remains around $3800 \mathrm{~W}$, as shown on the $4^{\text {th }}$ row of Fig. 8 , but not enough to satisfy the load demand. The $2^{\text {nd }}$ row of Figure 8 shows the battery SOC; we observe that the battery is charging up to $90 \%$ at $15^{\text {th }}$ second from the start of the simulation and stops. The energy management algorithm disconnects the battery from charging. As soon as the wind power output drops to zero, the algorithm dispatches the battery for a period ranging from $55^{\text {th }}$ second to $80^{\text {th }}$ second to support the PV system to match the overall microgrid load. From the $80^{\text {th }}$ second, the wind power picks up again while the load decrease from $12000 \mathrm{~W}$ to $6000 \mathrm{~W}$. The system disconnects the battery and sets it to default. From the $100^{\text {th, }}$ as the decrease in the load demand reaches

Mehran University Research Journal of Engineering and Technology, Vol. 41, No. 1, January 2022 [p-ISSN: 0254-7821, e-ISSN: 2413-7219] 


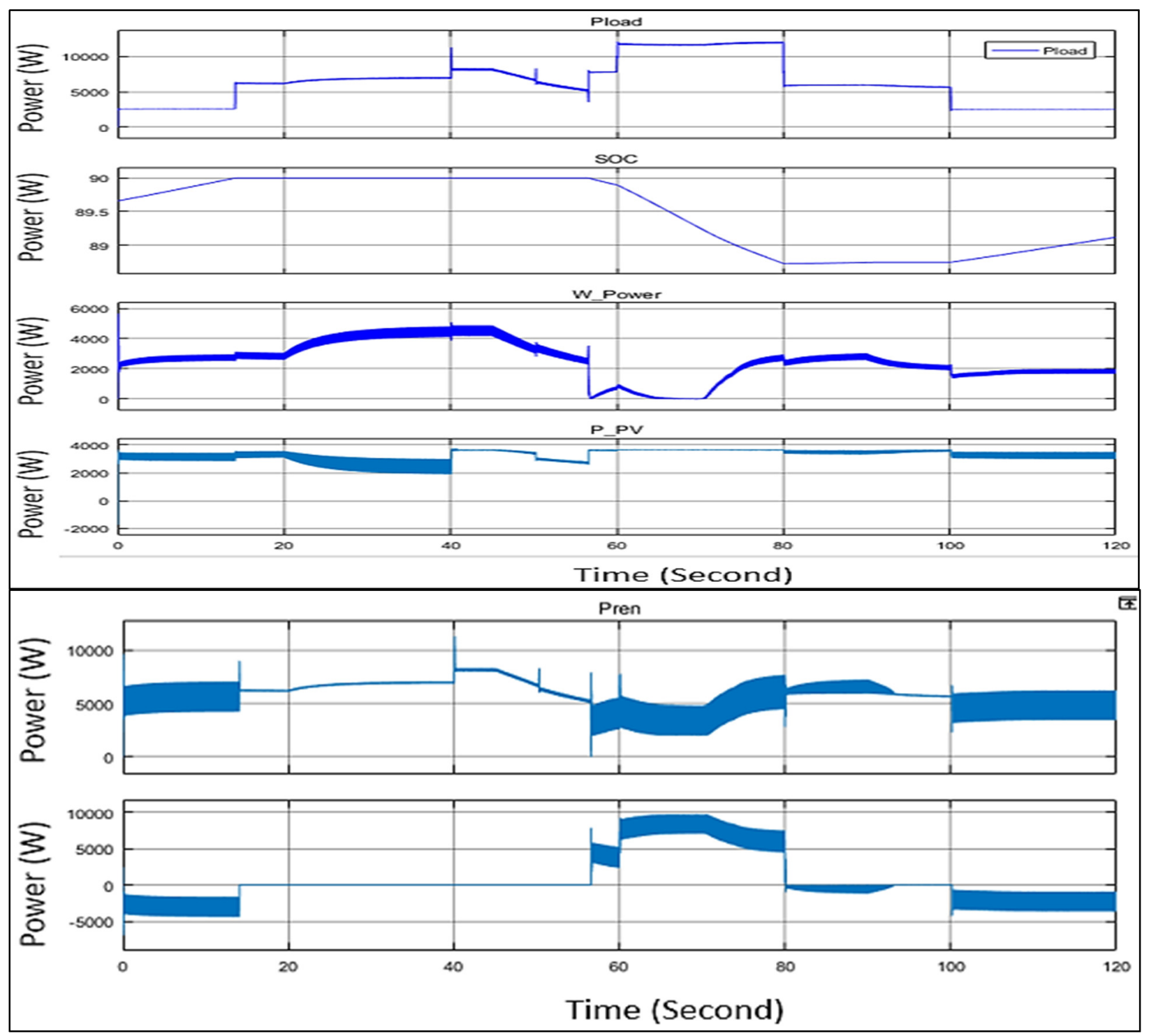

Fig. 8: Power Load, SOC of Battery, Wind Power, Photovoltaic Power, Power Generated by Renewable Energy and Battery Power

$2500 \mathrm{~W}$, the energy management system set the battery to charge. The 5th and 6th rows show the combined power generated by the renewable energies and the battery respectively. Table 7 shows a summary of the results for the $3^{\text {rd }}$ scenario.

With the three scenarios, it is proved that the the proposed energy management system successfully tracks the load change and dispatches the resources following the predefined criterias. Morever the algorithm can be slightly modified to add new option such as energy export, in the scheme of peer to peer energy trading.

\begin{tabular}{|c|c|}
\hline \multicolumn{2}{|c|}{ Table 7: Summary of the $3^{\text {rd }}$ Scenario Results } \\
\hline Name & Value \\
\hline Load & $\begin{array}{l}\text { Size }=12000 \mathrm{~W} \\
\text { Highest load }=12000 \mathrm{~W} \\
\text { Lowest load }=3500 \mathrm{~W}\end{array}$ \\
\hline Battery & $\begin{array}{l}\text { Initial } \mathrm{SOC}=89 \% \\
\mathrm{SOC}_{\min }=40 \% \\
\mathrm{SOC}_{\max }=90 \% \\
\text { Battery power }=9000 \mathrm{~W}\end{array}$ \\
\hline PV+ Wind Turbine & $\begin{array}{l}\text { Maximum power }=8000 \mathrm{~W} \\
\text { Minimum power }=3000 \mathrm{~W} \\
\text { Voltage }=230 \mathrm{~V}\end{array}$ \\
\hline
\end{tabular}

Mehran University Research Journal of Engineering and Technology, Vol. 41, No. 1, January 2022 [p-ISSN: 0254-7821, e-ISSN: 2413-7219] 


\section{CONCLUSION}

The energy access is a challenge for rural community and renewable energy based hybrid residential microgrid emerged as a viable solution. However, the management of these resources requires an energy management system. Thus, this paper proposed an energy management system algorithm for a residential hybrid microgrid system. The later consists of a photovoltaic system (PV), wind turbine, and a battery based energy storage system. The proposed energy management aims at an equitable dispatch of the available power from the renewable resources; and at the same time implement various scheme during contingency that might rise due to the intermittence nature of the renewable energy resources. For testing and validation the system is simulated over a residential off-grid microgrid model developed in Matlab/Simulink environment. Three scenarios are tested, they emulate the normal condition, sudden load increasing combined with a fluctuation in the renewable power resource; and a complete loss of one resource. The results show that the proposed energy management system, successfully manages the supply and the demand balance within the microgrid. It shows its ability to perform an adequate power resources dispatching during renewable resource energy fluctuations, through the control of energy storage system cycles. By the battery cycles control, the proposed energy management system protects the battery system from overcharging damages. Unlike others systems as presented in the introduction, the energy system presented in this paper is less complex, economic and easy to upgrade. The proposed system can be applied to grid connected or in peer to peer energy trading.

\section{REFERENCE}

1. Chand A.A., Parasad A.K., Mamun A,K, Islam F.R., Manoj N.K., Rajput P., Sanjivikumar P., "Microgrid Modeling and Simulation", In Sanjivikumar P., Nithiyananthan K., Karthikeyan S.P., Holm-Nielsen J.B. (Eds.): Microgrids, pp. 59-79, Chapter 4, CRC Press, 2020.

2. Grover M., Egbue O., "Analysis of Key drivers and challenges facing microgrid deployment", Proceedings of the 5th International Conference on Smart and Sustainable Technologies, (SpliTech), pp. 1-5, Split, Croatia, 23-26 September 2020.

3. Soshinskaya M., Crijns-Granus W.H.J., Guerrero J.M., Vasquez J.C., "Microgrids: Experiences, barriers and success factors", Renewable and Sustainable Energy Reviews, Vol. 40, pp. 659672, 2014.

4. Abo-Al-Ez K.M., Xia X., Zhang J., "Smart interconnection of a PV/wind DG microgrid with the utility distribution network", Proceedings of the $9^{\text {th }}$ Industrial and Commercial Use of Energy Conference, pp. 1-8, Cape Town, South Africa, 15-16 August 2012.

5. Lu X., Wang J., Guo L., "Using microgrids to enhance energy security and resilience", The Electricity Journal, Vol. 29, No. 10, pp. 8-15, 2016.

6. Salomonsson D., Soder L., Sannino A., "An adaptive control system for a DC microgrid for data centres", IEEE Transactions on Industry Applications, Vol. 44, No.6, pp. 1910-1917, November-December 2008.

7. Kashem S.B., De Souza S., Iqbal A., Ahmed J., "Microgrid in military applications", Proceedings of the $12^{\text {th }}$ International IEEE Conference on Compatibility, Power Electronics and Power Engineering, pp. 1-5, Doha, Qatar, 10-12 April 2018.

8. Cox D.J., "Microgrid Infrastructure Modeling in Residential Microgrids", IEEE Power Engineering Society General Meeting, pp. 1-6, Tampa, F.L., U.S.A., 24-28 June 2007.

9. Ganji M., Shahidehpour M., "Development of a residential microgrid using home energy management systems", In Lamont L.A., Sayigh A., Application of Smart Grid Technologies, pp. 173-192, Academic Press, 2018.

10. Justo J.J., Mwasilu F., Lee A.J., Jung J.W., “AC Microgrids versus DC Microgrids with distributed energy resources", Renewable and Sustainabale Energy Reviews, Vol. 24, pp. 387405, 2013.

11. Zsiboracs H., Baranyai N.H., Vincze A., Zentko K., Birkner Z., Mate K., Pinter G., "Intermittant renewable energy sources: The role of energy storage in the european power system of 2040", Electronics, Vol. 8, No. 7, 2019. 
12. Murty V.V.S.N., Kumar A., "Multi-objective energy management in microgrids with hybrid energy sources and battery energy storage systems", Protection and Control of Modern Power Systems, Vol. 5, No.2, 2020.

13. Jaya S.L., Kirubakaran V., "A critical review on hybrid renewable energy based micro-grid system for sustainable management", Journal of Critical Reviews, Vol.7, No.12, pp. 432-436, 2020.

14. Nejabatkhah F., Li Y.W., "Overview of Power Management Strategies of Hybrid AC/DC Microgrid", IEEE Transactions on Power Electronics, Vol. 30, No. 12, pp. 7072-7089, 2015.

15. Kanechev H., Lu D., Calos F., Lazarov V., Francois B., "Energy management and operational planning of a microgrid with a PV based active generator for smart grid applications", IEEE Transactions on Industrial Electronics, Vol. 58, No.10, pp. 4583-4592, 2011.

16. Pourmousavi S.A., Nehrir M.H., Colson M.C., Wang C., "Real time energy management of a standalone hybrid wind microturbine of a standalone wind micro-turbine energy system using particle swarm optimization", IEEE Transactions on Sustainable Energy, Vol.1, No.3, pp. 193-201, 2010.

17. Solanki B.V., Canizares C.A., Bhattacharya K., "Practical energy management systems for isolated microgrids", IEEE Transactions on Smart Grid”, Vol. 10, No.5, pp. 4762-4775, 2018.

18. Li Y., Nejabatkhah F., "Overview of control, integration and energy management of microgrids", Journal of Modern Power Systems and Clean Energy, Vol. 2, No.3, pp. 212-222, 2014.

19. Su W., Wang J., "Energy management system in microgrid operations", The Electricity Journal, Vol. 25, No. 8, pp. 45-60, October 2012.

20. Upadhyay S., Sharma M.P., " Selection of a suitable energy management strategy for a hybrid energy system in a remote rural area of India", Energy, Vol. 94, pp. 352-366, 2016.

21. Olatomiva L., Mekhilef S., Ismail M.S., Moghavvemi M., "Energy management strategies in hybrid renewable energy systems - a review", Renewable and Sustainable Energy Reviews, Vol. 62, pp. 821-835, 2016.
22. Luta D.N., Raji A.K., "Energy management system for a hybrid hydrogen fuel cellsupercapacitor in an isolated microgrid", Proceedings of the Southern African Universities Power Engineering Conference/Robotics and Mechatronics, /Pattern Recognition Association of South Africa, Bloemfontein, South Africa, pp. 611-615, 28-30 January 2019.

23. Kafetzis A., Ziogou C., Panopoulos K.D., Papadopoulos S., Seferlis P., Voutetakis S., "Energy management strategies based on hybrid automata for islanded microgrids with renewable sources, batteries and hydrogen", Renewable and Sustainable Energy Reviews, Vol. 134, 2020.

24. Vera Y.E.G., Dufo-Lopez R., Bernal-Agustin L., "Energy management in microgrids with renewable energy sources: A literature review", Applied Sources, Vol. 9, No. 18, 2019.

25. Shirazi E., Jadid S., "Optimal residential appliance scheduling under dynamic pricing via HEMDAS”, Energy and Buildings, Vol. 93, pp. 40-49, 2015.

26. Häberlin H., "PV Installation Sizing", Photovoltaics, pp. 507-551, West Sussex, U.K., John Wiley \& Sons, 2012.

27. Bouharchouche A., Berkouk E. M., Ghennam T., "Control and energy management of a grid connected hybrid energy system PV-wind with battery energy storage for residential applications", Proceedings of the 8th International Conference and Exhibition on Ecological Vehicles and Renewable Energies (EVER), pp. 1-11, Monte Carlo, Monaco, 27-30 March 2013. 